Language in Africa 1(3), 2020, 336-352. doi: 10.37892/2686-8946-2020-1-3-336-352

\title{
IDEOPHONES IN DZO (JENJO), AN ADAMAWA LANGUAGE OF NORTHEASTERN NIGERIA
}

\author{
Peace Benson \\ Federal University Wukari \\ peacebenson71@yahoo.com
}

\begin{abstract}
Ideophone is a phenomenon dominant in African languages. Dzə is an under-investigated and under-documented Adamawa language found in Taraba, Adamawa and Gombe States, Northeastern Nigeria. It was noticed that the language has a lot of ideophones. It became necessary to study it to understand its importance in the language. This study is to draw the attention of scholars working on Adamawa languages and ideophones. It will also thus form part of the grammar of Dzo someday. The study of ideophone is not exhaustive, especially in the minority languages of Northeastern Nigeria. The study shows that Dzə ideophones express intensity, emphasis and description. Dzə ideophones have unique phonological features and some of the sounds found in the conventional phonology of Dzə are not found in the ideophones. The phoneme $/ \mathrm{y} /$ is common in the coda position of the ideophones. Ideophones modify verbs, adjectives and nouns in Dzə. They also function as adverbs and are elements that constitute a noun phrase. They augment other word classes like nouns, verbs and adjectives.
\end{abstract}

Key words: Jenjo, ideophones, grammatical functions, Dzə, Adamawa languages, Taraba 


\section{Introduction}

Dzə [jen] is an Adamawa language ${ }^{1}$ the language is spoken in some parts of Adamawa, Taraba and Gombe States in Northeastern Nigeria. The endonym is $D z$ b but the language is widely known by the exonym Jenjo. "Adamawa languages are among the least documented in Africa" (Kleinewillinghöfer 2016: 1). Dzə is a poorly studied language. Its speakers are predominantly in Jen (their capital home), Karim-Lamido local government area of Taraba state. According to Eberhard and al. (2020), it has 100,000 user population.

Ideophones are an integral part of African languages. ${ }^{2}$ Blench (2009) reiterated this fact when he states that a characteristic feature of languages worldwide, but particularly those in Africa is ideophones, words of a distinct semantic type, which can fill one or many syntactic slots. Ideophones were first known by early researchers to be features of African onomatopoeia but now there are cross-linguistic analyses of ideophones in the Indo-European languages. There are several perceptions as to what an ideophone is (see Kilian-Hatz 2001; Dingemanse \& Majid 2012; Jacques 2013; Beck 2008). Crystal (2008) defines ideophones as a term used in linguistics and phonetics for any vivid (ideophonic) representation of an idea in sound, such as occurs through onomatopoeia. From the above definition, we can see that ideophones have to do with sounds, onomatopoeia, ideas and perceptions. Ideophones in Dzo will, therefore, be examined with that in mind.

According to Blench (2010) most publications in general have focused on Niger-Congo languages. While it is true that a lot has been

${ }^{1}$ Adamawa is the classificatory label for about ninety languages, spoken in the central part of the sub-Saharan savannah belt (Sudan zone), in an area which stretches from the mountains bordering the basins of the Middle Benue and the Lower Gongola in northeast Nigeria across the north of Cameroon to the east into Chad and the Central African Republic (Kleinewillinghöfer 2016).

2 Dingemanse has worked extensively on ideophone of an African language see Dingemanse (2012; 2013; 2015) and Dingemanse \& Majid (2012). 
written about Niger-Congo languages, there are not much studies on the ideophones of Adamawa languages. The few available are (Anonby 2008; Bohnhoff 2019). Bohnhoff (2019) gave a detailed description of Dii ideophones. In the same vein, the study of ideophones is not exhaustive, especially on small group languages of Northeastern Nigeria. Similarly, Pischedda (2017) states that despite scholars' interest in problems relating to functions and cross-linguistic aspects of ideophones, there are still areas that remain under-researched. For example, the expressive and creative role played by ideophones in comic books or an Anglophonic influence in the use of ideophones in Portuguese, Spanish or French Disney comics etc. Besides that, the forms of ideophones differ in languages.

This research follows the basic linguistic theory as described by Dixon (2010). It is a single cumulative theory which views each language as a complete linguistic system. It is the theory of linguistics as a natural science that involves studying and comparing the grammatical patterns of individual languages. It is eclectic in nature because it is a blend of several theories that can be used to address all levels of language.

The data was collected during fieldwork in $\mathrm{Jen}^{3}$ (the capital city of the Dzo people) in December 2014. Three Dzo folktale tellers were approached and with their consent, the folktales were recorded. Each told two to three tales. The bulk of the data for this study was collected through the recorded folktales. The recorded folktales were transcribed and translated using Saymore ${ }^{4}$ and the ideophones elicited. Participant observation of daily conversations of people at home and churches were noted.

This section presents an introduction of the study, framework and methodology used in the study. Section 2 concentrates on tone and

${ }^{3}$ Jen is one of the alternate names of Dzo and also the town of the Jenjo people located along the Benue river of the Karim-Lamido Local Government Area of Taraba State.

${ }^{4} \mathrm{https}: / /$ software.sil.org 
phonological properties of Dzə ideophones. Morphological properties of ideophones are discussed in Section 3. Section 4 examines syntactic properties ideophones and section 5, the semantic properties of Dzo ideophones, conclusion in section 6 and lastly, there is a list of Dzo ideophones in Appendix.

\section{Phonological properties and tone}

\subsection{Phonemic inventory}

According to Othaniel (2014), Dzə has thirty-three consonant phonemes: $/ \mathrm{p}, \mathrm{b}, \mathrm{t}, \mathrm{d}, \mathrm{c}, \mathrm{f}, \widehat{\mathrm{kp}}, \widehat{\mathrm{gb}}, \mathrm{k}, \mathrm{g}, \widehat{\mathrm{ts}}, \widehat{\mathrm{dz}}, \widehat{\mathrm{t} \mathrm{f}}, \widehat{\mathrm{d}}, \mathrm{n}, \mathrm{y}, \mathrm{m}, \mathrm{m}, \mathrm{n}, \mathrm{f}, \mathrm{v}$, $\mathrm{s}, \mathrm{z}, \int, 3, M, h, 1, j, j, \mathrm{y}, \mathrm{\varphi}, \mathrm{w} /$. The sounds that occur in Dza ideophones are $\mathrm{b}, \mathrm{p}, \mathrm{t}, \mathrm{d}, \widehat{\mathrm{kp}}, \widehat{\mathrm{gb}}, \mathrm{k}, \mathrm{g}, \widehat{\mathrm{ts}}, \widehat{\mathrm{dz}}, \widehat{\mathrm{t}}, \widehat{\mathrm{d}} \mathrm{z}, \mathrm{n}, \mathrm{y}, \mathrm{m}, \mathrm{n}$, $\mathrm{f}, \mathrm{v}, \mathrm{s}, \mathrm{z}, \int, 3, \mathrm{~h}, \mathrm{l}, \mathrm{j}, \mathrm{w} /$. The following sounds do not occur in Dza ideophones: the voiceless bilabial nasal $/ \mathrm{m}_{0} /$; voiceless velar fricative $/ M /$; voiceless palatal approximant $/ \mathrm{j} /$; voiceless palatal approximant $/ \mathrm{y} /$ and voiced palatal approximant $/ \mathrm{\zeta} /$. The voiceless velar approximant $/ \mathrm{w} /$ does not occur alone in the ideophones except in a con-

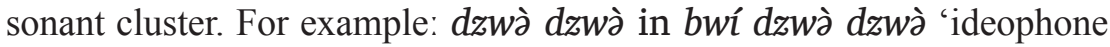
that describes softness', and bwàn bwàn 'ideophone that describes something tight and small'. Furthermore, the consonant phoneme /r/ i.e. the voiced alveolar trill $[\mathrm{r}]$ occurs in ideophones such as hàr 'sound of coming in a hurry' and bìr 'sound of flying birds'. But it is not found in the Dzo consonant phoneme. The voiced bilabial plosive /b/, voiceless alveolar plosive $/ \mathrm{t} /$ and voiceless velar plosive $/ \mathrm{k} /$, voiced affricate velar $/ \mathrm{y} /$ and their variants are the most common phonemes in ideophones which are found in large numbers, more than any other sound and its variants. The majority of ideophones have a consonant $/ \mathrm{y} / \mathrm{in}$ coda position. This is probably because Dzo is rich in consonant $/ \mathrm{y} /$. They can occur in onset, medial and coda of all word classes including ideophones.

According to Othaniel (2014), Dzo has nine oral vowel phonemes:

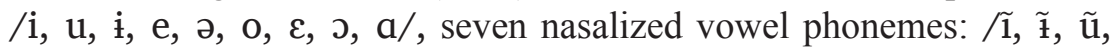


$\tilde{\partial}, \tilde{\varepsilon}, \tilde{\jmath}, \tilde{\mathrm{a}} /$ and six breathy vowel phonemes: /ị, ụ, e e, ọ, ə̣, ạ/. There is vowel harmony in Dzə ideophones with -ATR vowels [ə, $\varepsilon$ ]. Usually, the -ATR vowel [ə] can co-occur with any other vowel but in the ideophones, it occurs only with - ATR vowel $[\varepsilon]$ or itself. Such ideophones are kwàte in tsà kwàté 'very hard', tàkpé tàkpé 'sound of milling'. The +ATR vowels [i, u] co-occur as in kúní kúní 'state of walking and moving shoulders to each side with each step'. There is no \pm ATR vowel harmony between the nasalized and breathy vowels in the ideophones. We have not experienced any breathy vowel in the ideophones but there are nasalized vowels e.g. $b$ z̃̀b ̃̃̀ 'describes anything

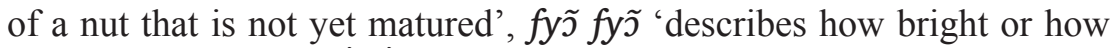
light something is', kû̀kũ̃ 'describes something or someone short'. The ideophone tūtū will sometimes lengthen a vowel $l^{5}$ for emphasis. For example, yè tūtū 'horrible smell' can be emphasised as yè tūtūūūū 'extremely horrible smell'. This is also attested by Anonby (2008: 402) in the ideophones of Mambay.

\subsection{Syllable structure}

According to Othaniel (2014), Dzo has six basic syllable types: V, CV, CVC, CCV, N and VC. ${ }^{6}$ However, only three syllable structure types were evident in Dze ideophones. They are as follows.

\section{(1) $\mathrm{CV}$ \\ (2) $\mathrm{CCV}$}

ğbà 'manner-less'

a. zhầ zhã̀ 'ideophone that describes thick, big lips'

nwá mà Zhằzhã̀

mouth 2SG IDEO

'your thick big mouth'

${ }^{5}$ More on vowel lengthening see Gussman (2002).

${ }^{6}$ See Othaniel's (2014) phonology write up. 


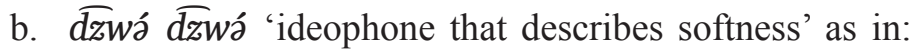

bwí

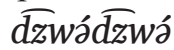

soft

IDEO

'quiet soft'

(3) $\mathrm{CCVC}$

a. bwàn bwàn 'ideophone that describes something small and tight'

b. kyán kyán 'ideophone 'that describes something long and tight'

Dzə ideophones are mostly disyllabic with a default shape /CVCV/. Ideophones in Dzo have only one reduplicative pattern which is the full reduplicated ideophones. Trisyllabic ideophones are rare.

(4) bùlùlù 'ideophone for sleepy or sexy eye'

tòlòlò 'ideophone for motion or walking foolishly'

kàlàlà 'ideophone that describes loudness'

The trisyllabic ideophones are not common. They seem like partial reduplication but are not because there are no forms to be traced back to morphophonologically to show that these trisyllabic ideophones are partially reduplicated. Another reason is that there are no ideophones such as bùlu, tòlò or kàlà for partial reduplication to take place. They are also characterized by identical tone and vowel.

\subsection{Tone}

The Dzo language has three primary tone levels and contours involving all three levels. These are H, M and L tones (5).
(5) $\mathbf{H}$
M
$\mathbf{L}$
bí 'song'
bì 'metal'
bì 'word'
kí 'stalk'
kì 'mat'
kì 'prune'
wá 'fry'
$w \bar{a}$ 'pluck'
wá 'roast' 
(6) shows examples of contour tones involving $\mathrm{H}$ and $\mathrm{L}$.

(6) $\mathbf{H L}$

kǔ 'belch'

प̨ě 'red monkey'
LH

tîn 'capsize'

tâ 'father'

Contour tones involving $\mathrm{M}$ are exemplified in (7).

(7) $\mathrm{MH}$

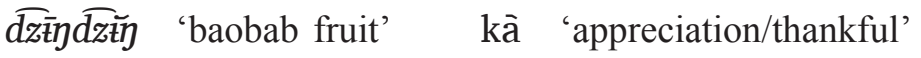

LM

fämā 'a kind of fish'

These primary tone levels and contour tones are also found in Dzo ideophones and most of the ideophones are disyllabic as seen in the appendix below. It is seen that there are disyllabic ideophones with the tone melodies HH, MM, LL, LH, LR, and LM in Dzo, the dominant tone pattern is LL and MM. There are tone melodies that are not found in Dzo disyllabic verbs but are found in Dzo disyllabic nouns and ideophones. These are LH and LM. Out of the 84 ideophones, there are six monosyllabic ideophones that carry the same L tone; and one tone melody in the trisyllabic Dzo ideophones which is LLL as against the conventional Dzo trisyllabic nouns which have HHH, HHM and HHL.

\section{Morphological properties}

Morphologically, ideophones in Dzo have no inflection. This is unlike other word categories in Dzə such as nouns and verbs that inflect for number, tense and aspects respectively.

Fully reduplicated ideophones express intensity, as in (8).

(8) a. nwà

mouth

'His mouth is very dirty.'

b. nwà

mouth

'His mouth is extremely dirty.' bí zítt́

black/dirt IDEO

bí

black/dirt IDEO IDEO 

c. sò $n$ hò gúdú
1SG NPST walk IDEO
'(S)he walks heavily.'

$\begin{array}{llll}\text { d. sò } & n & \text { hò gúdú gúdú } \\ \text { 1 } \mathrm{SG} & \text { NPST } & \text { walk IDEO IDEO } \\ \text { '(S)he walks extremely heavily.' }\end{array}$

zúté zúté in (8b) and gúdú gúdú in (8d) express intensity respectively. We see that in (8a) and (8c) the single ideophones did not carry the amount of intensity/seriousness the reduplicated ideophones did. The difference in marking intensity and emphasis is that intensity uses reduplication while emphasis uses vowel lengthening. There are more fully reduplicated ideophones than the non-reduplicated ones as the fully reduplicated ones are likely more to be used than the nonreduplicated root (see the list of Dzo ideophones in Appendix 1). Fully reduplicated ideophones are certainly one of the features of African ideophones as attested by Okoye \& Egenti (2015: 58) on Etulo ideophones and Asohsi (2018) on Bafut. This could imply that African ideophones are rich in reduplication.

\section{Syntactic properties of ideophones}

Dzə ideophones may follow nouns, verbs or adjectives, i.e. they modify the elements they follow. An example an ideophone that modifies a noun is presented in (9).
(9) ò
jí
$b \bar{e}$
nyívī
$f \grave{\varepsilon} f \bar{\varepsilon}$
$3 \mathrm{SG}$ wake with morning IDEO
'(S)he wakes up early morning.'

In (9), f̌̌̀f $\bar{\varepsilon}$ modifies the noun nyívi, the ideophone tells us that he or she wakes early. It modifies the noun when it follows the noun in noun phrases or sentences.

An ideophone modifying a verb is presented in (10). 
$\begin{array}{llllllll}\text { (10) ihyue fànī và } & \text { ibwì dè chí } & k w \tilde{\varepsilon} & k w \tilde{\varepsilon} \\ \text { maize farm GEN } & \text { man } & \text { DET } & \text { to.be.dry } & \text { IDEO } & \text { IDEO }\end{array}$

'The maize in the man's farm is very dry.'

An ideophone modifying an adjective is presented in (11).

$\begin{array}{lllll}\text { (11) nị } & \text { ìmwà } & \text { dè } & \text { hyã̀ } & k p a ̀ n g \\ \text { eye } & \text { child } & \text { DET } & \text { red } & \text { IDEO }\end{array}$

'The child's eye is very red.'

In (10), the ideophone $k w \tilde{\varepsilon} k w \tilde{\varepsilon}$ modifies the verb chí 'to be dry'. In (11), the ideophone kpàng modifies the adjective hyã̀ 'red'.

\subsection{As adverbs}

Payne (1997) states that Any word with semantic content (i.e., other than grammatical particles) that is not clearly a noun, a verb, or an adjective is often put into the class of adverb. Adverbs in Dzo are adverbs of information and usually modify verbs, verb phrases or clauses. (12) examplifies how this works in Dzə.

(12) sè $n$ yìdí pì tá bē wà tày và sì Yeso they NPST want LOC go with $3 \mathrm{SG}$ in house LOC Jesus 'They want to take him to the house to see Jesus.'

The additional information si Yeso 'to Jesus' is an adverb of information because the proposition can be complete without the addition.
(13) íbwì bánsè $n \bar{t} \quad \tilde{f}$
man Fulani DEM to.be.tall IDEO
dé táká
DET went

'The Fulani man that is very tall took the cows away. (lit. Fulani man that/who is tall kàlàntày took the cows away.'

In (13), the phrase $\grave{f}$ k̇laytəy appears to give us more information on how tall the man is. Therefore, an adverb of information. The ideophone also modifies the stative verb fĭ. 
(14) à pé kwán kwán wú à pé bì ò bà má $2 \mathrm{SG}$ bend IDEO IDEO come $2 \mathrm{SG}$ pass lest $3 \mathrm{SG}$ see $2 \mathrm{SG}$

'You bend quietly pass lest (s)he sees you.'

In (14), the phrase à pé kwán kwáy 'you bend quietly' is an additional information in the clause because the remaining part of the clause wú à pé bì ò bà 'come and pass before she/he sees you' is a complete proposition. kwán kwán modifies the verb pé 'bend' and expresses the manner of the bend.
(15) vò
ijé
dè $b i ́$
zìtt́ zùtt́
house woman DET black/dirt IDEO IDEO
'The woman's house is very dirty.'

The occurrence of ideophones may or may not be conditioned by verbs, adjectives or nouns they modify. For example kàlàntày cannot

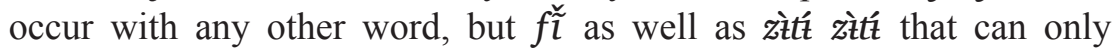
occur with bí.

In Dzə, và ìjé dè bí can be a complete proposition. The ideophones zìté zìt ít is additional information. It also modifies the verb bí, therefore, it is seen as an adverb here. The ideophones in examples (13)-(15) all function as adverbs.

\subsection{As elements of a noun phrase}

Ideophones constitute one of the elements that form a noun phrase in Dzə. They occur with a head noun to form a noun phrase, as in (16) to (18). The ideophones that modify nouns either precede or follow the nouns.

\section{(16) kpìntìn kú \\ IDEO head \\ 'heavy/big head'}

The ideophone kpìntìn and the noun kú 'head' can be seen as a noun phrase as is the case in bànlán nwà 'big wide mouth'. 
(17) bànlán nwà

IDEO mouth

'big/wide mouth'

The ideophones in (16) and (17) can occur with either kú or nwà i.e. we can have bànlén kú and kpìntìn nwà. When the phrase kpìntìn kú occur alone, the kú carries a high tone but if it occurs in clause like (18) below it carries a low tone.

(18) ímwà $n \dot{i}$ kù kpì̀tìn $n \dot{t} \quad s \dot{t} \quad n \quad$ wí child DEM head IDEO DEM LOC NPST come 'That child that has big head is coming.'

(19) nwà wà bànlán

mouth 3sG.POSS IDEO

'His mouth big and wide.'

\section{Semantic properties}

The semantics of ideophones are about expressivity, i.e. they are expressing the meaning of the senses they evoke. This is in line with Jacques (2013: 263) and Okoye \& Egenti (2015: 58) who posit that ideophones describe various features like sound, smell, taste, shape, texture, colour etc. Jenjo ideophones express sound, shape, texture, feeling, state, degree and colour as the following examples show: Ideophones that describe sound e.g. kpăkpá kpăkpá 'sound of horns hitting against a tree', kpònò kpònò 'atmospheric sound', gúdú gúdú 'sound of heavy, large feet on the ground like elephant feet'. Ideophones that describe shape e.g. bànlón 'wide'. Ideophones that describe texture e.g. bùtú bùtú 'fine textured smooth flour'. Ideophones that describe feelings e.g. yỳy 'the feverish feeling'. Ideophones that describe state

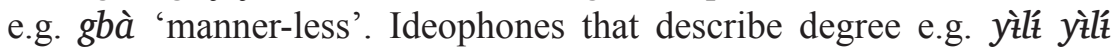
'something extremely cool', ỳ̀ż́ 'very cool' and ideophones that describe colour e.g. kpàng 'shows how bright a colour is'. Ideophone that describes smell e.g. tùtù 'horrible smell', mùmù 'nice smell'. The 
ideophones of sounds, smell and feelings can be used with noun phrases, verbs, or stative verbs as in the examples below.
(20) $p \dot{t}$ sí $n$
wà

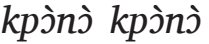
place LOC NPST sound IDEO IDEO
'The place sounds empty.'

The verb wà 'sound' is modified by the ideophone kpònว̀ kpòǹ̀.
(21) níndzwà
yé tùtù
wound 3SG smell IDEO
'His/her wound smells bad.'

The ideophones for degree, colour and texture may modify adjectives and stative verbs respectively, cf. (22) to (24).

(22) nínmárí dè tấ yàlte yìlté rice DET be.cold IDEO IDEO

'The rice is very cold.'

(23) yốy basí

leaf kind of tree with orange flower DET ADJ IDEO

'very red flower'

(24) nín wò hyõ̀ kpày

eye 3sG.POSS red IDEO

'his/her very red eye'

The word la is an adjective signifying red and this ideophone seems to be the only ideophone that can modify this particular adjective.
(25) yámwuì và kwì ìjé
dè fá
bùtú bùtú
flour GEN old woman DET be.smooth IDEO IDEO
'The old woman's flour is extremely smooth.'

\section{Conclusion}

We noticed that the language has a lot of ideophones. It became necessary to study it to understand its importance in the language. This study is to draw the attention of scholars working on Adamawa 
languages and ideophones. Ideophones are frequently used in Dzə folktales as well as everyday conversations. The unique features of Dzə ideophones are seen throughout the study. Morphologically, Dzo ideophones have no inflection and in the syntactic aspect, they function as adverbs. Ideophones in Dzə augment and modify other word classes like nouns, verbs and adjectives. They express intensity and emphasis through reduplication and final vowel lengthening. The difference in marking intensity and emphasis is that intensity uses reduplication while emphasis uses vowel lengthening. They hardly precede the word they modify. It is rare but only happens with nouns as in the case of bànlán nwà and nwà wà bànlán.

\section{Abbreviations}

$1 \mathrm{SG}-1^{\text {st }}$ person singular

$2 \mathrm{SG}-2^{\text {nd }}$ person singular

$3 \mathrm{SG}-3^{\text {rd }}$ person singular

ADJ - adjective

ATR - advanced tongue root

$\mathrm{CV}$ - consonant vowel

CVC - consonant vowel consonant

DEM - demonstrative

DET - determiner

GEN - genitive

$\mathrm{H}$ - high tone

$\mathrm{HL}$ - high low tone
IDEO - ideophone

$\mathrm{L}$ - low tone

LOC - locative

LH - low high tone

LM - low mid tone

$\mathrm{M}$ - mid tone

$\mathrm{MH}$ - mid high tone

$\mathrm{ML}$ - mid low tone

$\mathrm{N}$ - Nasal

NPST - non-past tense

POss - possessive

$\mathrm{V}$ - Vowel

\section{Appendix. Lists of Dzə ideophones}

\begin{tabular}{|c|c|}
\hline Ideophone & Meaning \\
\hline báplán & to be big and wide \\
\hline bj̀b̀̀ & describes something small and tight \\
\hline bĩ̀b & describes anything of a nut that is not yet matured \\
\hline bìr & describes sound of flying bird or insect \\
\hline bùlùtù & sexy/sleepy eye \\
\hline
\end{tabular}


Continuation of Appendix

\begin{tabular}{|c|c|}
\hline bùtú bùtú & describes fine textured flour that is very smooth \\
\hline bùtùm & sound of someone or something that has fallen \\
\hline bwàn bwán & describes something tight and small \\
\hline bwùjì & the sound of something like a building collapsing \\
\hline byj̀ byó & describes how tears fall from someone's eye \\
\hline $\operatorname{ch} \bar{\jmath} \operatorname{ch} \bar{\jmath}$ & describes something that is very sour \\
\hline$d \overline{\tilde{\varepsilon}} d \overline{\tilde{\varepsilon}}$ & describes how someone or something runs \\
\hline$d \grave{t} d \grave{t}$ & describes something or a place that is very clean \\
\hline dín dín & describes when something is full to the brim \\
\hline dódó & desscribes something or someone that is the only one \\
\hline dzwá dzwá & decribes something that is soft \\
\hline$f \grave{\varepsilon} f \bar{\varepsilon}$ & describes early hours of the morning or midnight \\
\hline fă fàn & describes something or place that is very open \\
\hline 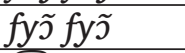 & describes the brightness of red colour \\
\hline$g \overline{b a ̀}$ & to stand mannerlessly on someone sitting down \\
\hline gbày gbày & sound from a big drum \\
\hline gbintin & describes something or a place that is dark \\
\hline gàytáj & describes something that is very bitter \\
\hline gว̀gว̀ & be rough \\
\hline gìgì & describes the reaction of someone being anxious, angry etc \\
\hline gìtì & describes someone walking with all strength and energy \\
\hline gùdù gùdù & $\begin{array}{l}\text { describes someone or something with large heavy feet } \\
\text { running heavily }\end{array}$ \\
\hline hàlàlà & describes watery soup, stew or porridge \\
\hline hàr & describes that someone or something is coming in a hurry \\
\hline jìng & describes act of moving one's neck to look elsewhere \\
\hline jōjjō & $\begin{array}{l}\text { describes someone that shakes as a result of sickness or } \\
\text { anger }\end{array}$ \\
\hline$k \bar{e} k \bar{e}$ & drink down \\
\hline kàlàlà & describes the loudness of a shout \\
\hline kàlàytày & describes how tall someone or something is \\
\hline$k \bar{\partial} s \hat{\varepsilon}$ & describes someone or something that is very white \\
\hline$k \overline{\tilde{\jmath} k \overline{\tilde{z}}}$ & describes the degree of boiling \\
\hline kínkín & descsribes light steps of tiptoeing \\
\hline
\end{tabular}


Continuation of Appendix

\begin{tabular}{|c|c|}
\hline kírkír & describes someone running heavily \\
\hline kùnènè & describes someone that is greedy and covetous \\
\hline kúní kúní & $\begin{array}{l}\text { descibes the state of walking and moving shoulders to each } \\
\text { side with each step }\end{array}$ \\
\hline$k \tilde{u} k \stackrel{\tilde{u}}{~}$ & describes someone or something short \\
\hline$k \bar{u} t w i$ & describes shape of something thick and round \\
\hline kpǎkpá kpǎkpá & $\begin{array}{l}\text { describes the sound of horns hitting against another horns } \\
\text { or tree }\end{array}$ \\
\hline kpày & describes the brightness of red colour \\
\hline kpāntāy & decribes how white someone or something is \\
\hline kpì̀ kpì̀ & sound from a small drum \\
\hline 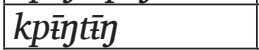 & describes something that is big and heavy \\
\hline kpว̀nว̀ kpว̀nว̀ & $\begin{array}{l}\text { describesthe sound of distance noise or commotion } \\
\text { (atmospheric sound) }\end{array}$ \\
\hline kyว̀y kyว̀y & something that is long and tight \\
\hline 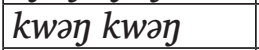 & describes the manner in which someone bends \\
\hline$k w \bar{t} t \bar{\varepsilon}$ & describes how hard something is \\
\hline 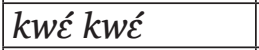 & describes how dry something is \\
\hline lày lày & up high \\
\hline lùbí & sound of water or something falling in water \\
\hline lùlú & describes water that is lukewarm \\
\hline mùmù & pleasant or nice smell \\
\hline дcháj лnchán & broken to pieces \\
\hline nwà jwwà & describes when something is plenty and unorganized \\
\hline$\eta w \bar{a} \eta$ & sound of bowel movement when hungry \\
\hline nwā̄ n $n w \bar{a} \eta$ & sound of grains cooking in a tin container \\
\hline п๊̄ $\mu \bar{\partial} \eta$ & describes something plenty \\
\hline pàpí & hurry \\
\hline$p \bar{\partial} t \bar{\varepsilon}$ & describes how flat something is \\
\hline$p \bar{u} \bar{a}$ & describes sound of slap on the cheek \\
\hline pùpù & describes an area or place that is swampy, loamy ground \\
\hline pwàpû & sound of falling \\
\hline$p w \grave{\varepsilon} p w \grave{\varepsilon}$ & bloated/kwashiorkor stomach \\
\hline$s \grave{\varepsilon} s \grave{\varepsilon}$ & describes feeling lightweighted and happy \\
\hline
\end{tabular}


End of Appendix

\begin{tabular}{|c|c|}
\hline 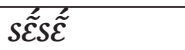 & describes a bright place or atmosphere \\
\hline$s w \hat{\varepsilon} s w \grave{\varepsilon}$ & describes how tears fall from the eyes \\
\hline tว̌kpé tว̌kpé & sound of milling especially with a grinding stone \\
\hline tètť̀ & describes how vast or empty something is \\
\hline$t \overline{\bar{\nu}} t \overline{\tilde{\nu}}$ & describes distance/farness \\
\hline tòlòlò & describes someone or something walking foolishly \\
\hline tǒtó & describes something that is shining \\
\hline$t \bar{u} t \bar{u}$ & horrible smell \\
\hline tùtù & full to the brim \\
\hline twán twán & quiet place \\
\hline yàté yàlé & describes the degree of coolness of something \\
\hline yı̀ỳ̀ & describes feverish condition \\
\hline zhã zhã & describes that something is thick and big \\
\hline zìtt́ zìtt́ & describes how dirty someone or something is \\
\hline zùzù & sound of liquid or watery things pouring \\
\hline zwà zwà & walking uncoordinatedly (shapelessly) \\
\hline
\end{tabular}

\section{References}

Anonby, Erik John. 2008. Phonology and morphology of Mambay (NigerCongo, Adamawa). Leiden: Univ. of Leiden. (Ph.D. dissertation.)

Asohsi, Melvice. 2018. Ideophones in Bafut. Journal of West African Languages 45(1). 125-141.

Beck, David. 2008. Ideophones, adverbs and predicate qualification in Upper Necaxa Totonac. International journal of American linguistics 74(1). 1-46.

Bohnhoff, E. Lee. 2019. A description of Dii phonology, grammar and discourse. Ngaoundéré: Dii Literature Team.

Blench, Roger. 2009. The sensory world; ideophones in Africa and elsewhere. (http://www.rogerblench.info/RBOP.htm) (Accessed 2019-812.)

Blench, Roger. 2010. Mwaghavul expressives. (http://www.rogerblench. info/RBOP.htm) (Accessed 2019-8-12.)

Crystal, David. 2008. A dictionary of linguistics and phonetics. UK: Blackwell Publishing 
Eberhard, David M. \& Simons, Gary F. \& Fennig, Charles. D. (eds.). 2020. Ethnologue: Languages of the World. $23^{\text {th }}$ ed. Dallas, Texas: SIL International. Online version: http://www.ethnologue.com.

Dingemanse, Mark. 2012. Advances in the cross-linguistic study of ideophones. Language and Linguistics Compass 6. 654-672.

Dingemanse, Mark. 2013. Ideophones and gesture in everyday speech. Gesture 13. 143-165.

Dingemanse, Mark. 2015. Ideophones and reduplication: depiction, description, and the interpretation of repeated talk in discourse. Studies in Language 39(4). 946-970.

Dingemanse, Mark \& Majid, Asifa. 2012. The semantic structure of sensory vocabulary in an African language. Proceedings of the annual meetings of the Cognitive Science Society 34. 300-305.

Dixon, R. M. W. 2010. Basic linguistic theory: methodology. Vol 1. Oxford: Oxford University Press.

Jacques, Guillaume. 2013. Ideophones in Japhug (Rgyalrong). Anthropological Linguistics 55(3). 256-287.

Kilian-Hatz, Christa. 2001. Universality and diversity: ideophones from Baka and Kxoe. In Voeltz, F.K. Erhard \& Kilian-Hatz, Christa (eds.), Ideophones, 155-164. Amsterdam: John Benjamins.

Kleinewillinghöfer, Ulrich. 2016. Adamawa. In Voßen, Rainer \& Dimmendaal, Gerrit J. (eds.), Handbook of African languages, 220-230. Oxford: Oxford University Press.

Okoye, Adaobi Ngozi \& Chidimma, Egenti Martha. 2015. On Etulo ideophones. Journal of Humanities and Social Science 20(6). 56-59.

Othaniel, Nlabephee Kefas. 2014. Jenjo phonology statement. Unpublished manuscript

Pischedda, Pier Simone. 2017. Anglophonic influences in the use of sound symbolism in Italian Disney comic: A corpus-based analysis. Open Linguistics 3. 591-612. 